\title{
WARIA, PEMERINTAH, DAN HAK SEKSUAL: KASUS IMPLEMENTASI PERDA GEPENG DI DIY
}

\author{
Masthuriyah Sa'dan \\ (Peneliti Indonesian Consortium for Religius Studies, ICRS Yogyakarta)
}

\begin{abstract}
The Governor of DI Yogyakarta issued a regional regulation number 1 of 2014 on the handling of homeless and beggars. The transvestites who sang on the sidewalk, on the sidewalk and at the red lights also became the main target of the apparatus. So that those arrested do not receive humane treatment in the assessment camp including services in sexual and reproductive health for transsexuals living with HIV / AIDS. Though singing for transvestites may be "the only" way to survive in the city of Yogyakarta. By using literature review, this paper would like to examine why she-male singing and how the attitude and responsibility of the state to fulfill the human right for she-male.
\end{abstract}

Keywords: She-male, goverment, sexual rights.

\section{A. PENDAHULUAN}

Bagi kaum miskin kota (KMK), kota Yogyakarta bukan kota yang manusiawi lagi. Bagaimana tidak, Gubernur Daerah Istimewa Yogyakarta mengeluarkan peraturan daerah nomor 1 tahun 2014 tentang penanganan gelandangan dan pengemis dengan tujuan untuk mencegah terjadinya gelandangan dan pengemis, memberdayakan gelandangan dan pengemis, mengembalikan dan gelandangan pengemis dalam kehidupan yang bermartabat dan tujuan yang terakhir adalah menciptakan ketertiban umum. ${ }^{1}$ Akibat dari peraturan daerah itu, banyak kaum miskin kota menjadi korban karena mengalami pelbagai bentuk tindakan dan perlakuan yang tidak prosedural. Di antaranya adalah kekerasan fisik, psikis, ekonomi dan sosial, penangkapan secara sewenang-wenang, kadang salah tangkap layaknya penculikan, perlakuan tidak manusiawi dan pengabaian di camp assessment, pemaksaan ekspresi gender terhadap waria yang ditangkap, serta tindakan lain yang menunjukkan pelanggaran hak asasi manusia. $^{2}$

Dikeluarkannya perda itu menjadi bumerang terhadap kaum miskin kota untuk bisa bertahan hidup (survive) di kota Yogyakarta. Perda itu seolah-olah melahirkan perlakuan diskriminatif karena menjadikan seseorang sebagai kriminal hanya karena miskin. Di sinilah sebenarnya terjadi konsep "kriminalisasi" pendefinisian kaum miskin. Bahwa kaum miskin kota adalah gelandangan dan pengemis. Bahwa mereka yang berjalan menggunakan baju compang-camping di jalan adalah gelandangan. Padahal tidak semua orang menggunakan baju compang camping adalah gelandangan, pengalaman korban yang ditangkap secara paksa dijalan oleh aparat adalah mereka kuli bangunan yang baru selesai bekerja dengan

\footnotetext{
${ }^{1}$ Peraturan Daerah Istimewa Yogyakarta tentang Gelandangan dan Pengemis nomor 1 tahun 2014, dalam $\frac{w w w . d p r d \text {-diy.go.id }}{2}$

Press Release "Perda Gepeng Membunuh Kami”, edisi 26 April 2016 dalam https://kaukusperdagepengdiy.wordpress.com
} 
menggunakan baju lusuh dan sobek, tetapi diseret oleh aparat karena diklaim sebagai gelandangan.

Kasus yang dialami oleh kuli bangunan, pengamen dan gelandangan lainnya yang disikut aparat di tengah jalan juga dialami oleh para waria. Menurut penuturan Ibu Shinta Ratri, para waria yang mengamen di pinggir jalan, di trotoar dan di lampu merah juga menjadi incaran utama aparat. Padahal mengamen bagi waria mungkin "satu-satunya" cara untuk tidak mengatakan tertutupnya akses pekerjaan lain bagi waria untuk bertahan hidup di kota Yogyakarta. Waria yang terdiskriminasi dari keluarga dan sosial, tidak memiliki bekal pendidikan dan tidak memiliki akses lapangan pekerjaan harus menanggung beban hidup yang lebih berat karena perda gepeng telah membuat kelompok waria masuk dalam target pembersihan dari aparat. Seolah-olah, pemerintah tidak memiliki ide lain atau tidak punya cara lain untuk mengurangi angka kemiskinan di kota Yogyakarta selain harus menyiduk dan menyikat habis orang miskin di kota termasuk waria. Kemudian setelah ditangkap, para pengamen, waria, pengemis, dan orang gila yang terdiri dari anak-anak, perempuan, tua muda, dan lansia diletakkan di dalam satu sel kamar tahanan. Di ruangan itu tidak ada perlakuan khusus untuk waria yang terjangkit penyakit HIV/AIDS, padahal waria yang mengidap penyakit yang demikian, merupakan tanggung jawab negara untuk memberikan pelayanan kesehatan tanpa melihat identitas gender.

Sungguh ironi melihat pemerintah dewasa ini, pemerintah melihat waria atau kaum miskin kota layaknya sampah yang harus dibersihkan, ditampung di sel tahanan dan dicampur dari berbagai macam manusia. Namun pemerintah berbaik hati mendukung pembangunan apartemen dan hotel-hotel masuk ke kampung-kampung padat penduduk, sehingga menggusur petani dari yang mulanya bercocok tanam menjadi buruh hotel, merangsang anak perempuan dan remaja perempuan masuk dalam sindikat prostitusi, ibu-ibu mengalami kekeringan sumur sehingga kekurangan air untuk mencuci dan memasak, dan pelbagai risiko negatif lainnya. Berdasarkan data Dinas Perizinan kota Yogyakarta, pada penghujung akhir 2015, izin pembangunan hotel yang diajukan sebelum kebijakan moratorium dikeluarkan pada 2014 berjumlah sebanyak 104 buah izin bangunan hotel baru. Kemudian dipenghujung akhir 2015, terdata sekitar 81 IMB yang sudah diterbitkan oleh Dinas Perizinan pemkot kota Yogyakarta dan di akhir April 2016, izin bangunan hotel baru itu naik menjadi 84 IMB yang telah terbit. ${ }^{3}$ Di sini, melihat implementasi perda gepeng seakan-akan menegaskan bahwa pemerintah dalam membuat regulasi kebijakan pembangunan menegasikan hukum tajam ke bawah tetapi tumpul ke atas. Padahal memberikan pelayanan kepada kelompok marginal adalah sebuah keniscayaan bagi pemerintah.

Tulisan ini ingin menjawab dua pertanyaan, mengapa waria memiliki profesi sebagai pengemis dan pengamen, bagaimana sikap dan tanggung jawab negara memenuhi hak-hak seksual kelompok waria. Tujuan dari tulisan ini adalah melihat waria dari perspektif humanisme dengan pemenuhan hak-hak seksual yang menjadi hak hidup bagi kelompok waria sebagai warga negara Indonesia. Bentuk tulisan ini adalah kajian pustaka dengan pendekatan humanisme dan analisa studi kasus di Daerah Istimewa Yogyakarta.

3 "Selama persyaratan lengkap, Pemkot Yogyakarta akui tak bisa menolak pembangunan hotel", edisi Selasa, 12 April 2016, dalam http://jogja.tribunnews.com 


\section{B. Realita Hidup Waria di Yogyakarta}

Di negeri ini, banyak orang yang menegosiasikan laki-laki yang tertarik dengan lakilaki lain dengan feminitas. Namun mereka kadangkala menolak streotipe feminin yang dilabelkan kepadanya. Bahkan, sebutan "banci" seringkali ditolak karena karena kata "banci" mengandung stigma merendahkan dan konotatif yang tertanam di dalamnya. Itulah sebabnya, pegiat hak asasi kelompok LGBT (lesbian, gay, biseksual dan transgender) lebih memilih kategori waria karena mengandung political correct. ${ }^{4}$ Di samping itu, nama pondok pesantren yang menjadi tempat para transgender di kota Yogyakarta belajar agama Islam diberi nama pondok pesantren waria.

Untuk lebih mempermudah kategori, terdapat perbedaan antara seorang gay dengan seorang waria. Menurut Dede Oetomo, identitas seorang waria terjadi di kelas menengah ke bawah. Artinya, ada gay yang kadangkala berdandan sebagai waria, dan sebaliknya kadangkala seorang waria berpenampilan seperti seorang gay. Dalam bahasa yang lebih sederhana, batas antara seorang gay dengan seorang waria hakikatnya adalah batas sosiologis yang dibentuk dalam kesadaran sebagian besar kaum gay dan waria itu sendiri. ${ }^{5}$

Menurut Danadjaja, waria merupakan kelompok transeksual atau transgender, yaitu kaum homo yang mengubah bentuk tubuhnya dapat serupa dengan lawan jenisnya. Contoh dari mereka dapat dilihat pada seorang laki-laki yang mengubah dadanya dengan operasi plastik atau suntik silikon, membuang penis, serta testisnya dan membentuk lubang vagina. Sebagian besar transeksual adalah laki-laki yang mengenali dirinya sebagai perempuan, yang timbul ketika masa kanak-kanak dan melihat alat kelamin dan penampakan kejantanannya dengan perasaan jijik. ${ }^{6}$ Hesti dan Sugeng mengungkapkan beberapa faktor penyebab terjadinya transeksual antara lain: pertama, faktor biologis yang dipengaruhi oleh hormon seksual dan genetik seseorang. Kedua, faktor psikologi dan sosial budaya termasuk pula pola asuh lingkungan yang membesarkannya. Ketiga, memiliki pengalaman yang sangat hebat dengan lawan jenis, sehingga mereka berkhayal dan memuja lawan jenis sebagai idola dan ingin menjadi seperti lawan jenis. ${ }^{7}$

Dalam tataran sosial budaya masyarakat Indonesia, eksistensi transgender bukanlah sesuatu yang aneh. Mereka ada di sekitar kehidupan kita. Masyarakat biasanya melihat seseorang yang terlahir dengan jenis kelamin laki-laki, berpenampilan feminin dan menggunakan pakaian perempuan di acara-acara komedi televisi, di salon kecantikan, di jalanan sebagai pengamen atau sebagai pekerja seks. Namun jarang sekali, untuk tidak mengatakan sedikit sekali melihat transgender memiliki profesi "bermartabat" menurut anggapan umum masyarakat. Hampir tidak "terlihat" waria yang bekerja di sektor pendidikan, baik sebagai guru, tenaga kependidikan maupun dosen atau yang memiliki profesi di transaksi keuangan misal perbankan. Sebagian masyarakat menerima waria dalam batas tertentu, yaitu dalam streotipe waria, sebagai bahan lawakan, sebagai pekerja salon kecantikan dan sebagai pekerja seks atau pelacur.

\footnotetext{
4 Tanti Noor Said, "Politik Gender \& Seksualitas: Transgender Indonesia dalam konteks masyarakat Indonesia dan Eropa Barat", dalam Jurnal Perempuan edisi 87 volume 20 no. 4 November 2015, hlm. 110.

${ }^{5}$ Dede Oetomo, Memberi Suara Pada Yang Bisu, Yogyakarta: Pusaka Marwa, 2003, hlm. 42.

${ }^{6}$ Lihat James Danadjaja, "Homoseksual atau Heteroseksual" dalam Srintil: Menggugat Maskulinitas \& Feminitas, Jakarta: Kajian Perempuan Desantara, 2003.

${ }^{7}$ Lihat Hesti Puspitosari \& Sugeng Pujileksono, Waria \& Tekanan Sosial, Malang: UMM Press, 2005.
} 
Rully dan Endang yang bekerja sebagai pengamen di pertigaan Maguwo Yogyakarta menjadi contoh nyata bagaimana dua orang waria berusaha bertahan hidup di kota Yogyakarta, usaha dua orang waria itu juga mungkin dilakukan oleh banyak waria lain di Yogyakarta dan di luar kota lainnya. Seperti yang ditulis oleh Hartoyo, bahwa Rully pernah mengajar di Sekolah Dasar di Propinsi Nusa Tenggara Timur, akan tetapi karena mendapat cemoohan dari salah satu muridnya, dan Rully merasa terpukul, akhirnya Rully memutuskan untuk menanggalkan status Pegawai Negeri Sipil dan kemudian berkeliling Indonesia dan beberapa negara untuk mencari identitas diri. Hingga akhirnya Rully menetap di Yogyakarta dan menyelesaikan pendidikan sarjana jurusan seni tari di Institut Seni Indonesia. Di Yogyakarta inilah Rully kemudian bergabung dengan LSM Kebaya, sebuah organisasi yang membantu waria dalam menangani penyakit HIV dan AIDS. ${ }^{8}$

Berbeda dengan Rully yang berlatar pendidikan tinggi, Endang "hanya" menamatkan pendidikannya di Sekolah Dasar. Orang tua Endang berada dalam taraf ekonomi keluarga miskin dan Endang meninggalkan keluarganya sejak remaja. Karena lari dari keluarga, tanpa bekal pengetahuan dan keahlian yang cukup untuk bekerja di sektor formal. Untuk menyambung hidup Endang bekerja sebagai pekerja seks komersial di Taman Lawang Jakarta Pusat. Namun karena usia sudah tua dan pelanggannya berkurang, sedangkan hidup butuh untuk makan, maka satu-satunya cara yang bisa dilakukan oleh Endang adalah mengamen di pertigaan lampu merah Maguwo. Mereka mengamen di pertigaan Maguwo sejak dari pukul 10.00-17.00 dengan pendapatan rata-rata setiap harinya antara 30.000-s/d 100.000 dengan catatan tidak ada razia dari satpol PP. Dua orang waria itu mengamen di pertigaan lampu merah karena tidak ada cara lain untuk membeli sesuap nasi kecuali dengan cara meminta belas kasihan orang lain yang mengendarai mobil. Pekerjaan lain selain mengamen tidak dapat mereka lakukan karena terbatasnya akses lapangan pekerjaan untuk waria.

Peraturan daerah tentang gelandangan dan pengamen di Daerah Istimewa Yogyakarta membuat para waria kehabisan akses lapangan untuk bertahan hidup dengan cara yang "halal". Padahal cerita dan pengalaman hidup Rully dan Endang untuk bertahan hidup di kota Yogyakarta adalah dua dari ribuan wajah waria di negeri ini. Mereka adalah cermin waria yang berada dalam garis kemiskinan yang mengalami diskriminasi sebagai warga negara dengan hak-hak yang seharusnya dimiliki. Selain tidak memiliki akses lapangan pekerjaan, didiskriminasi dari lingkup kelurga, masyarakat, dan pertemanan, identitas gender mereka juga tidak diakui dalam catatan administrasi kependudukan sipil. Sehingga tak heran, kalau banyak waria yang tidak memiliki Kartu Tanda Penduduk (KTP).

\section{Pemerintah \& Praktik Kekerasan}

Secara teori, Max Weber mendefinisikan kekuasaan sebagai kesempatan yang ada pada seseorang atau sejumlah orang untuk melaksanakan kemauannya sendiri dalam satu tindakan sosial. Weber menghubungkan kesempatan itu berkaitan dengan ekonomi, kehormatan, partai poltik, atau dengan apa saja yang merupakan sumber kekuasaan bagi seseorang. ${ }^{9}$ Weber memberikan penekanan bahwa kekuasaan lahir karena seseorang dinilai memiliki otoritas. Di sini otoritas dimaknai sebagai sebuah kemungkinan di mana perintah-

\footnotetext{
${ }^{8}$ Hartoyo dkk., Ekspresi untuk Identitas, Jakarta: Suara Kita, PKBI, dan Renebook, 2014, hlm. 75-76.

${ }^{9}$ Ridwan, Kekerasan Berbasis Gender: Rekonstruksi Teologis, Yuridis, \& Sosiologis, Purwokerto: PSG STAIN, 2006, hlm. 64-65.
} 
perintah tertentu datang dari sumber-sumber tertentu akan ditaati oleh sekelompok orang tertentu. Kemudian, Weber membagi otoritas ke dalam tiga bagian, antara lain; pertama, otoritas tradisional-otoritas yang didasarkan pada suatu kepercayaan yang sudah mapan akan kekudusan tradisi-tradisi zaman dahulu. Kedua, otoritas legal-rasional, yaitu otoritas yang didasarkan pada komitmen, atau seperangkat aturan yang diungkapkan secara resmi dan diatur secara impersonal. Ketiga, otoritas karismatik, yaitu otoritas yang didasarkan pada mutu luar biasa yang dimiliki oleh seorang pemimpin sebagai seorang pribadi.

Konsep korelasi antara kekuasaan dengan kekerasan di kemukakan oleh Thomas Hobbes, bahwa manusia bertindak atas dasar kepentingan diri dan menjadi fitrah manusia untuk berselisih dan bertengkar. Penguasa atau pemerintah memiliki kekuasaan yang tidak terbatas termasuk menggunakan kekerasan dalam mempertahankan kekuasaannya. Hubungan kekuasaan merupakan hubungan yang eksploitatif dan represif. Kekuasaan menjadi sangat nyata dalam hubungan sosial yang tidak seimbang. Kekerasan yang dilakukan oleh penguasa dengan otoritas kekuasaannya merupakan model kekerasan struktural dan sistemik yang biasa dilakukan oleh negara. Kekerasan itu pada umumnya berangkat dari pandangan state centered dalam rangka melakukan kontrol terhadap masyarakat, sekaligus untuk melanggengkan kekuasaannya. ${ }^{10}$

Berkaitan dengan masalah kekerasan oleh pemerintah dalam konteks masyarakat miskin kota Yogyakarta adalah perda gepeng, yang termanifestasikan dalam berbagai regulasi yang melahirkan ketidakadilan. Pemerintah DIY sebagai salah satu institusi memiliki otoritas legal-rasional yang memiliki potensi melakukan kekerasan yang memarginalkan kelompok masyarakat tertentu (dalam hal ini seorang waria) yang dilegitimasi secara yuridis.

Implementasi Perda gepeng yang menyiduk kaum miskin kota Yogyakarta termasuk waria menimbulkan pelbagai persoalan kemanusiaan. Substansi perda gepeng yang seharusnya menjadi penanganan gelandangan dan pengemis, juga menjadi solusi untuk persoalan di jalanan ternyata justru menjadi instrumen peraturan daerah yang mencerminkan diskriminasi dan kekerasan oleh pemerintah. Perda gepeng itu mencerminkan kebijakan diskriminalisasi oleh pemerintah dan pelanggaran HAM kepada kaum miskin kota termasuk waria. Pertanyaannya kemudian, nilai apa yang dilanggar oleh gelandangan dan pengemis sehingga pemerintah sewenang-wenang memberikan stigma negatif dan mengkriminalisasikannya?

Dari banyaknya pelanggaran sebagai akibat implementasi perda gepeng, jaringan Kaukus untuk perda gepeng melakukan pengumpulan data kasus kekerasan pada implementasi perda gepeng No. 1 tahun 2014 sejak 21 September hingga 24 November 2015 terhadap orang-orang yang ditangkap dan ditahan di camp assessment. Kaukus menemukan 23 orang yang teridentifikasi mengalami pelanggaran HAM dan kekerasan. Pelanggaran HAM dan bentuk kekerasan itu antara lain: pertama, proses penangkapan yang sewenangwenang meliputi mendapat kekerasan fisik ketika proses penangkapan, penyeretan hingga terjatuh dan terluka juga kekerasan verbal melalui kata-kata penghinaan dan tidak pantas, kemudian mereka ditahan di camp assesment tanpa proses hukum yang jelas. Kedua, proses penahanan di camp assesment tanpa kejelasan dan penjelasan, di sini di ruang observasi semua yang ditangkap meliputi anak-anak, orang dewasa, dan gelandangan psikotik dicampur

\footnotetext{
${ }^{10}$ Ibid., hlm. 66.
} 
di dalam satu ruangan. Ketiga, proses pelayanan dan fasilitas di camp assessment yang tidak layak dan tidak manusiawi karena air berwarna cokelat, berbau besi dan kotor, sanitasi yang kotor, jumlah pekerja sosial yang mendampingi rasio 1:10 dengan situasi pekerja sosial tidak selalu berada di lokasi dan tidak bisa dihubungi sewaktu-waktu diperlukan. Keempat, hak makan dan hak pelayanan kesehatan tidak terurus. Seperti misalnya menu makanan yang tidak memenuhi gizi, tahanan yang haid tidak diberi pembalut, kebutuhan ODHA, kebutuhan anak-anak dan penyandang disabilitas tidak dipenuhi dengan baik, tahanan yang psikotik tidak diberi pengawasan yang baik dan bahkan ada tahanan psikotik yang meninggal dunia karena kelaparan. Kelima, prosedur dan proses pembebasan tidak jelas karena orang-orang yang ditangkap tidak mendapat kejelasan informasi kapan akan dibebaskan dan bagaimana prosedur pembebasannya. Keenam, Kerugian ekonomi selama dan pasca penahanan karena selama berada di tahanan para waria tidak bisa mengamen, padahal di samping mengamen, ada seorang waria yang juga berjualan keripik dengan penghasilan rata-rata sebulan 1.500.000 tetapi karena waria itu ditahan selama 5 hari di camp assessment dan tidak dapat melakukan kegiatan produktif, waria itu mengalami kerugian ekonomi sebesar 250.000 dan kehilangan pelanggan dari usaha keripik. ${ }^{11}$

Karena ditemukan banyaknya pelanggaran itu, maka Kaukus perda gepeng menyatakan sikap yang ditulis dalam media, bahwa Perda No. 1 Tahun 2014 merupakan bentuk kegagalan pemerintah DIY dalam pemenuhan hak-hak ekonomi, sosial, budaya, hak sipil, dan hak politik warga dalam bentuk kriminalisasi. Padahal kalau dikaji lebih detail tentang definisi kriminalisasi. ${ }^{12}$ Kriminalisasi adalah sebuah proses saat terdapat sebuah perubahan perilaku individu-individu yang cenderung untuk menjadi pelaku kejahatan dan menjadi penjahat, dengan berdasarkan pada definisi ini, maka perda gepeng dalam diksi kata "Pengemis \& Gelandangan" disamaartikan dengan sebuah tindak "Kejahatan". Padahal mempertanyakan lebih tajam kenapa waria berprofesi sebagai pengamen itu lebih bijak ketimbang menangkap mereka layaknya maling.

\section{Waria yang Mengamen}

Waria merupakan suatu gejala seseorang yang merasa memiliki seksualitas yang berlawanan dengan struktur fisiknya. ${ }^{13}$ Seksualitas menurut Leena Abraham tidak hanya mencakup identitas seksual, orientasi seksual, norma seksual, praktik seksual, dan kebiasaan seksual, akan tetapi juga perasaan, hasrat, fantasi, dan pengalaman manusia mengenai kesadaran seksual, rangsangan dan tindakan seksual, termasuk hubungan heteroseksual, serta hubungan homoseksual. Juga mencakup pengalaman subjektif serta pemaknaan yang melekat di dalamnya, seksualitas bukan saja perkara biologis dan psikologis, namun juga berdimensi sosial dan budaya dari identitas dan kebiasaan seksual. Kemudian Jeffer Weeks mendefinisikan seksualitas terjadi melalui relasi-relasi sosial, ekonomi, budaya, dan relasi kekuasaan. Seksualitas merupakan hasil dari pelbagai praktik sosial yang beraneka ragam, merupakan hasil dari pemaknaan sosial dan individual, hasil dari pergumulan antara mereka yang memiliki kekuasaan untuk mendefinisikan dan mengatur dengan mereka yang

11 "Ironi Jogja: ditetapkan kriminal hanya karena mereka miskin, sedangkan pembangunan industri pariwisata dan properti begitu dilayani”, edisi 9 Juni 2016, dalam https://kaukusperdagepengdiy.wordpress.com

${ }^{12}$ Ibid.

${ }^{13}$ Kartini Kartono, Psikologi Abnormal \& Abnormalitas Sexual, Bandung: Mandar Maju, 1989, hlm. 266. 
menentangnya. Di sini, Weeks mengartikan seksualitas bukan sebagai kodrat atau bawaan lahir, melainkan produk dari negoisasi, pergumulan dan perjuangan manusia. ${ }^{14}$

Sebagai seseorang yang memiliki seksualitas yang berlawanan dengan struktur fisiknya adalah waria. Istilah waria adalah akronim dari kata wanita pria atau wanita tetapi pria. Di kota-kota besar di Indonesia, waria bukan merupakan kelompok yang aneh. Banyak media dan rumah produksi serta perfilman nasional mengespos kaum waria sebagai komoditi yang menghadirkan kelucuan. Realita yang ada tidaklah selalu demikian, hanya bagian terkecil dari kaum waria yang memiliki hidup mapan secara finansial dalam eksistensi sosial. Bagian terbesar dari kaum waria memiliki profesi sebagai pelacur. Bahkan, meski di antara mereka memiliki pekerjaan tetap seperti karyawan salon, ahli kecantikan, pembantu rumah tangga, maupun pegawai, pekerjaan "keluar malam" selalu menjadi mata pencaharian utama kelompok waria di Indonesia. ${ }^{15}$

Risiko dari profesi itu dan risiko penyebaran penyakit kelamin oleh waria lebih tinggi dibandingkan dengan dunia pelacuran yang dilakukan oleh perempuan homoseksual. Kaum homoseksual maupun transeksual sering melakukan hubungan seperti sodomi, seks oral dan lain sebagainya. Kaum homoseks melakukan hubungan itu secara ajeg dan konsisten, disertai dengan hubungan bebas sesama kawan atau dengan orang lain. ${ }^{16}$ Perilaku seksual yang sering melibatkan pergantian pasangan sering juga membawa pengaruh terhadap sensitifnya penularan sebuah penyakit. Hasil penelitian Atmojo di atas yang dilakukan terhadap waria di Jakarta, bahwa $67,01 \%$ waria memiliki profesi sebagai pelacur. Berbeda dengan hasil penelitian Atmojo, hasil penelitian yang dilakukan oleh Koeswinarno, bahwa waria dan prostitusi adalah sebuah fenomena yang melekat dan sulit dipisahkan. Hal itu karena waria berpandangan bahwa mereka adalah minoritas dari kelompok sosial mayoritas dan menikah dengan laki-laki adalah obsesi yang tidak mungkin terjadi. Dari dua hal itulah, banyak dari waria yang terdorong untuk mengambil banyak kesempatan, jika memang ada sedikit kesempatan. $^{17}$

Terlepas dari alasan dan faktor mengapa waria memilih menjadi pelacur. Mengamen juga merupakan mata pencaharian waria untuk bertahan hidup. Melihat waria "hanya" dari sisi pekerjaan sebagai pelacur dan pengamen sepertinya kurang proporsional. Sebagai manusia yang berpengetahuan, ada baiknya melihat waria di balik profesi "tidak bermartabat" itu, kenapa dan mengapa waria memilih pekerjaan ini. Hal itu karena, sesuatu bisa terjadi karena ada latar dan sebab yang menyebabkan perbuatan itu dilakukan. Sependek pembacaan penulis, tentang kisah hidup waria dan juga interaksi penulis dengan beberapa teman-teman LGBT (Lesbian, Gay, Biseksual, dan Transgender), ada beberapa faktor waria memilih pekerjaan mengamen dan mengemis sebagai mata pencaharian. Di antaranya adalah:

Pertama, adanya diskriminasi dari keluarga terhadap waria. Umumnya keluarga belum bisa menerima kehadiran anggota keluarganya yang bertingkah dan berprilaku tidak sama dengan komunitas sosial, karena penolakan kehadiran waria dalam keluarga itulah maka

\footnotetext{
${ }^{14}$ Musdah Mulia, Mengupas Seksualitas: Mengerti Arti, Fungsi, dan Problematika Seksual Manusia Era Kita, Jakarta: Opus Press, 2015, hlm. 14-15.

${ }^{15}$ Kemala Atmojo, Kami Bukan Laki-Laki, Jakarta: Grafitti Pers, 1987, hlm. 24-25.

${ }^{16}$ W. Lindsay Neustatter, “Aspek-Aspek Medis Dalam Homoseksual”, dalam William A.R. Thomson (ed.), Sex dan Masalahnya, Yogyakarta: Yayasan Essentia Medica, 1987, hlm. 91.

${ }_{17}$ Koeswinarno, Hak-Hak Seksual: Deklarasi IPPF, diterbitkan oleh International Planned Parenthood Federation London, 2008, hlm. 79.
} 
penerimaan keluarga terhadap waria masih mendapat ganjalan dan konflik yang panjang. Mayoritas keluarga akan mengatakan menolak manakala ada salah satu anggota yang keluarga yang berani mengespresikan diri (coming out) sebagai waria. Biasanya keluarga akan beralasan bahwa waria adalah aib, pelaku dosa, pembuat malu keluarga, dan pelbagai macam stigma negatif lainnya. Risiko stigma negatif itu dialami oleh waria, tidak sedikit waria yang lari dari keluarga dan merantau jauh dari tanah kelahiran. Kedua, adanya diskriminasi sosial dari masyarakat sekitar waria hidup. Diskriminasi yang dilakukan oleh masyarakat adalah berupa kekerasan verbal seperti olokan, cemoohan, cibiran, hingga penghinaan mulai dari sebutan banci hingga bencong. Di samping itu, diskriminasi sosial itu melahirkan stigma negatif di lingkungan masyarakat. Bahwa waria adalah manusia abnormal, waria memiliki penyakit seksual, pekerjaan waria adalah pelacuran dan berbagai stigma negatif lainnya yang menyudutkan eksistensi waria dalam lingkup sosial. Ketiga, waria tidak memiliki keahlian khusus dan pengetahuan yang cukup karena pendidikan rendah. Pendidikan rendah itu terjadi karena waria merasa tersudutkan dalam lingkup sosial, baik di masyarakat, sekolah, komunitas permainan dan tidak diterima oleh keluarga, biasanya waria akan lari dari rumah. Itulah mengapa banyak waria yang tidak berpendidikan tinggi, sehingga mereka tidak memiliki keahlian khusus untuk bekal hidup. Keempat, tertutupnya untuk tidak mengatakan minimnya akses lapangan pekerjaan untuk waria. Hal itu karena lapangan kerja seperti di pabrik, misalnya hanya menerima karyawan dan pekerja yang memiliki keahlian khusus. Kemudian di lapangan kerja lain seperti birokrasi, politisi, akademisi, teknisi, dan berbagai pekerjaan lainnya melihat seseorang dari tingkat pendidikan. Tanpa bekal pendidikan, pengetahuan, dan keahlian khusus, maka siapa pun itu, baik hetero maupun homo, akan tergilas dari roda kehidupan.

Kelima, justifikasi negatif dari tafsir keagamaan tentang eksistensi waria. Penolakan terhadap eksistensi waria atas nama merupakan hal yang paling nyata dalam kehidupan waria. Peran agama menafikan realitas bahwa waria itu adalah kehidupan manusia. Akibatnya, keluarga, masyarakat, dan pemerintah selalu menggunakan legitimasi agama untuk mengokohkan alasan fundamental penolakan terhadap waria. Penafsiran keagamaan tentang waria baik yang tertulis dalam Alquran tentang kaum sodom maupun dalam hadist Nabi Muhammad Saw menjadikan waria mendapat perlakuan yang sadis dalam sejarah kehidupan umat Muslim. Sejarah kelam yang dialami oleh kelompok homo di masa kekhalifahan adalah ketika di zaman Khalifah Abu Bakar al-Shiddiq, khalifah pertama itu membunuh dengan cara membakar hidup-hidup kelompok homoseksual karena dianggap mengancam stabilitas pemerintahan dan umat Muslim, serta otoritas kekuasaan pada saat itu. Kemudian di masa khalifah kedua yaitu Umar bin Khattab, para homoseksual dihukum dengan cara di rajam hingga meninggal. Kemudian di era khalifah keempat, Ali Bin Abi Thalib membunuh para kaum homoseksual dengan cara diangkap ke menara tinggi lalu dibuang hingga meninggal dunia. Proses pembuangan kaum homoseksual itu disertai dengan ucapan Sayyidini Ali "Seperti inilah mereka akan dibuang ke dalam api neraka". ${ }^{18}$ Sejarah kelam kaum homoseksual dan tafsir keagamaan Islam yang memarginalkan waria berakibat kepada terbentuknya stigma bahwa waria adalah terlaknat, bahwa waria berdosa, bahwa tempatnya

${ }^{18}$ Rabab Abdulhadi, "Sexualities and The Social Order in Arab and Muslim Communities", dalam Samar Habib, Islam and Homosexuality, Amerika Serikat: ABC-CLIO, 2010, hlm. 467. 
waria adalah di neraka. Risiko dari stigma negatif yang bersumber dari tafsiran agama itu mewarnai konsep nilai dan norma yang berlaku di masyarakat. Efek terburuknya adalah waria termarginalisasi dalam lingkup keluarga, sosial, budaya, adat, tradisi, pemerintah, dan negara.

Keenam, mengamen adalah wadah pemberontakan diri waria terhadap sturuktur sosial yang melahirkan stigma dan label negatif terhadap eksistensi waria yang memiskinkan waria. Faktor yang keenam ini penulis kutip dari hasil obrolan dengan Ibu Rully yang sehari-hari mengamen di pasar dan aktif di organisasi Kebaya Yogyakarta. Menurutnya, mengamen bukan sekadar untuk mencari uang, tetapi merupakan usaha bagaimana agar masyarakat mengenal dan melihat bahwa diri waria itu ada dan hadir dalam kehidupan nyata sehari-hari. Untuk lebih jelasnya lihatlah tabel di bawah ini:

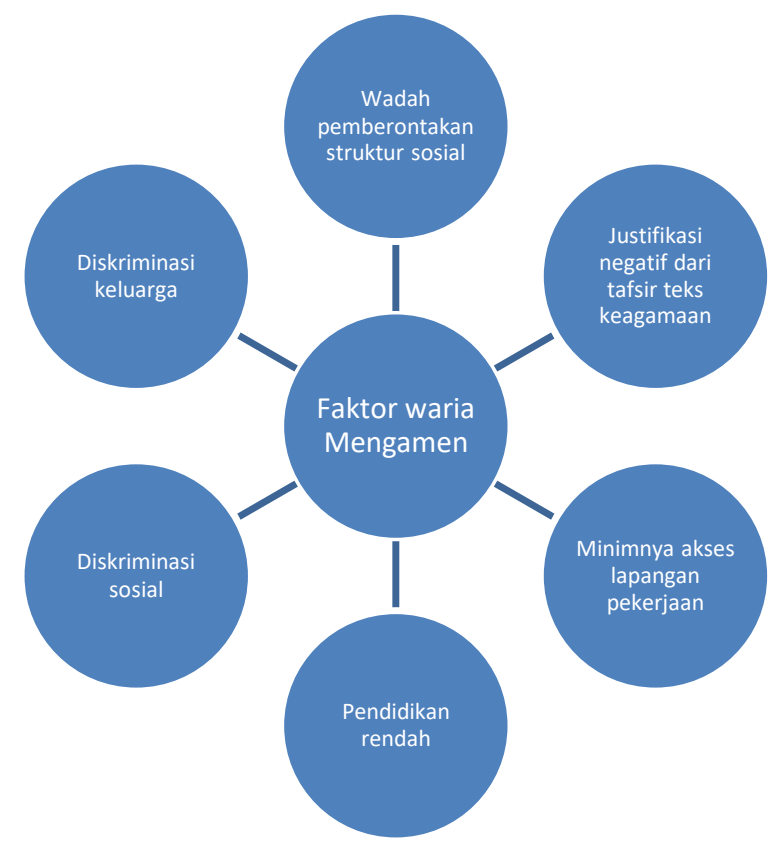

Tabel 01: Faktor-faktor waria mengamen

Dari beberapa faktor di atas, kita dapat memetakan bahwa latar belakang waria memilih jalan hidup sebagai pengamen itu bervariatif, bisa karena faktor desakan ekonomi bisa juga karena dorongan ekspresi identitas. Dengan demikian, penyamaan konsep antara waria dengan gelandangan dan pengamen yang tertulis dalam Peraturan Daerah DIY nomor 1 tahun 2014 tidak dapat digeneralisir secara mutlak. Karena setiap waria memiliki warna hidup berbeda-beda. Setiap waria memiliki jalan hidupnya masing-masing, tanpa harus ada intervensi dari pihak luar diri waria, termasuk pemerintah dan negara. Waria sebagai warga negara dengan latar belakang kisah hidup yang berbeda-beda dan dengan profesi yang di mata masyarakat "tidak" bermartabat, maka selayaknyalah pemerintah memberikan pelayanan sosial, fasilitas kesehatan, akses pendidikan, dan lapangan pekerjaan yang baik yang sama dengan warga negara lainnya. Namun, realita yang ada berbicara lain.

\section{E. Menggugat Tanggung Jawab Pemerintah}

Hak-hak seksual berhubungan dengan perangkat permasalahan yang berkaitan dengan seksualitas yang berasal dari hak atas kemerdekaan, kesetaraan, privasi, otonomi, integritas, 
dan harga diri dari semua manusia. Di samping itu, hak-hak seksual merupakan norma spesifik yang muncul ketika HAM yang ada diterapkan dalam hal seksualitas. Hak-hak seksual melindungi identitas tertentu, melindungi hak manusia untuk membolehkan, memenuhi, dan mengespresikan seksualitasnya dengan mengacu pada hak-hak yang lainnya, dan dalam kerangka kerja non diskriminasi. ${ }^{19}$ Pemenuhan hak-hak seksual itu yang merupakan tanggung jawab negara, akan tetapi negara sebagai penentu kebijakan publik abai dan lalai dalam pemenuhan hak-hak seksual, hal itu bisa dilihat pada hasil riset pada 2013 yang dilakukan oleh LSM Arus Pelangi yang menunjukkan bahwa 89,3\% LGBT di Indonesia pernah mengalami kekerasan karena identitas seksualnya, 79,1\% responden menyatakan pernah mengalami bentuk kekerasan psikis, $46,3 \%$ responden menyatakan pernah mengalami kekerasan fisik, 26,3\% kekerasan ekonomi, 45,1\% kekerasan seksual, 63,3\% kekerasan budaya. Bahkan kekerasan yang biasa dialami sudah diterima pada saat usia sekolah dalam bentuk bullying 17,3\% LGBT pernah mencoba untuk bunuh diri diri, dan 16,4\%-nya bahkan pernah melakukan percobaan bunuh diri lebih dari sekali. ${ }^{20}$

Perlakuan dinas sosial pemerintah Daerah Istimewa Yogyakarta ketika "pembersihan" gelandangan dan pengamen di area jalanan dan lampu merah kota Yogyakarta, termasuk di dalamnya waria merupakan tindakan dan sikap yang perlu dikaji ulang berdasarkan regulasi hukum peraturan Daerah Istimewa Yogyakarta. Hal itu karena ketika para waria diletakkan di camp assessmen mereka tidak mendapatkan perlakuan yang layak sebagai manusia dengan hak-hak yang harus ia terima. Seperti yang telah penulis singgung di bagian pendahuluan, bahwa ketika waria diletakkan dalam camp assessmen bersama dengan gepeng lainnya mulai dari anak-anak, remaja, dewasa, lanjut usia, orang gila, waria dan lain sebagainya. Para waria yang mengidap HIV/AIDS tidak mendapat pelayanan kesehatan. Padahal, waria memiliki hak kesehatan seksual dan reproduksi yang harus dilayani oleh pemerintah.

Hasil penelitian Danusukarto yang dikutip oleh Koeswinarno, bahwa cara penularan AIDS yang paling potensial adalah melalui hubungan homoseksual, termasuk di dalamnya kaum waria sebanyak $70 \%$, dan sisanya melalui kontaminasi jarum suntik $17 \%$, donor darah sebanyak $5 \%$, dan hubungan heteroseksual dengan pelacur perempuan sebanyak $8 \% .{ }^{21}$ Hasil penelitian itu menjadi indikator terbangunnya paradigma masyarakat bahwa waria rentan mengidap HIV/AIDS. Karena adanya paradigma yang menjustifikasi waria sebagai penyebab penyakit HIV/AIDS itu menjadikan waria tidak mendapatkan perlakuan yang manusiawi, bahkan justru mengutuk dan menghakimi. Padahal waria adalah manusia dengan harkat dan martabat yang ia miliki. Karenanya memperlakukan waria yang mengidap penyakit HIV/AIDS secara manusiawi merupakan tindakan yang mulia.

Jika waria yang mengidap HIV/AIDS berada dalam camp assessmen, seharusnya ditempatkan dalam ruangan yang terpisah dengan orang-orang yang tidak mengidap penyakit. Dan waria yang tidak mengidap penyakit juga di tempatkan di camp assessmen bersama dengan waria lainnya yang tidak mengidap penyakit. Di samping itu, yang tidak kalah pentingnya adalah mempertanyakan kembali tanggung jawab pemerintah terhadap kelompok waria. Pemerintah bertanggung jawab terhadap akses keamanan, keselamatan, dan kedamaian untuk seluruh warga masyarakat tanpa memandang jenis kelamin, orientasi seksual, profesi,

\footnotetext{
${ }^{19}$ Koeswinarno, Seksual, hlm. 23.

20 "Identitas Seksual dan HAM", dalam http://aruspelangi.org, diakses pada 19 April 2015.

${ }^{21}$ Koeswinarno, Seksual, hlm. 7.
} 
strata sosial, status sosial, dan agama. Hal itu karena, mau kita pungkiri bagaimanapun, orangorang homo memang ada dalam masyarakat kita, seperti juga di masyarakat-masyarakat lain di dunia ini. Inilah fakta yang tidak dapat diingkari.

Melihat implementasi perda gepeng yang mengesankan kekerasan oleh pemerintah terhadap warga masyarakat. Maka tanggung jawab pemerintah untuk meminimalisir kesan kekerasan itu adalah dengan melakukan tindakan beberapa hal. Antara lain: Pertama, Mengakui waria sebagai warga negara dengan cara memberikan mereka Kartu Tanda Penduduk (KTP). Tercatatnya nama seorang waria di catatan kependudukan menunjukkan bahwa eksistensi waria ada dalam lingkup administrasi negara dan pemerintah. Kedua, memberikan akses pendidikan yang sama dan setara. Akses pendidikan itu menjadi penting, mengingat pendidikan merupakan bekal hidup agar seorang waria dalam menjalani kehidupannya kelak memiliki skill dan pengetahuan yang cukup sehingga tidak tergilas oleh zaman. Ketiga, Memberikan akses layanan kesehatan termasuk untuk ODHA dan pendidikan kesehatan seksual dan reproduksi (kespro). Keempat, Memberikan akses lapangan pekerjaan. Kelima, Kesejahteraan ekonomi untuk waria dimasukkan dalam program kerja pembangunan daerah. Keenam, Menjamin hak-hak seksual, pendidikan, hidup, ekonomi dalam lain sebagainya untuk waria, sebagaimana layaknya jaminan hak-hak untuk kelompok hetero. Usulan tindakan kepada pemerintah seperti yang telah dijelaskan di atas menjadi urgen untuk dipertimbangkan, mengingat banyak sekali pengabaian pemerintah dan negara terhadap hakhak yang seharusnya dimiliki oleh waria sebagai warga negara.

Di samping itu, pelayanan untuk waria penderita HIV/AIDS, seharusnya dinas sosial melakukan beberapa hal, antara lain: pertama, menghibur dan meringankan penderitaan mereka dengan meminta mereka agar tetap tabah, tegar, semangat, dan mau menerima kondisi itu sebagai bagian kehidupan yang harus dilalui. Kedua, meyakinkan pasien bahwa penyakit HIV/AIDS bukanlah laknat, melainkan penyakit yang bisa menjangkiti siapa saja tanpa pandang bulu. Ketiga, meyakinkan pasien agar mau terbuka dan menerima kondisi dirinya apa adanya. Keempat, mengajak mereka untuk ikut serta dan terlibat dalam upaya-upaya penanggulangan penularan HIV/AIDS di masyarakat. Peran nyata waria dalam konstestasi kehidupan masyarakat menjadi niscaya, hal itu karena ketika waria ikut berperan serta dalam persoalan sosial masyarakat atau dalam kegiatan kemasyarakatan, maka lama-kelamaan eksistensi waria di masyarakat menjadi sebuah pertimbangan real-logis, bahwa waria tidak hanya berkutat dalam ruang lingkup dunia "esek-esek". Masyarakat bisa menerima keberadaan waria, tetapi waria harus menunjukkan hakikat keberadaan dirinya yang sesungguhnya.

Dengan demikian, pemerintah-dalam hal ini pemerintah Daerah Istimewa Yogyakarta-berkewajiban untuk memutus mata rantai kekerasan terhadap kelompok minoritas dan tertindas seperti waria. Mata rantai kekerasan terhadap waria dimulai dari hulu ke hilir. Di antaranya yang pertama adalah dari agama dengan cara mencari penafsiran teksteks keagamaan dari ayat Alquran dan Hadist yang cenderung berpihak kepada kelompok minoritas dengan asas keadilan (al-'adalah) dan kesetaraan (al-musawa). Sehingga dari hasil interpretasi itu dapat merubahan cara pandang masyarakat DIY tentang waria. Kedua, sosialbudaya, selama ini masyarakat memandang sinis dan benci terhadap eksistensi waria, kalaupun waria dianggap ada, masyarakat hanya menjadikan waria sebagai olokan, bahan tertawaan dan hinaan, padahal waria adalah bagian dari sistem sosial dengan kultur budaya 
yang membentuknya. Beberapa daerah tertentu di Indonesia masih mensakralkan sosok waria seperti di masyarakat Bugis dengan nama "bissu", di Ponorogo dengan nama sosok "warok" dan lain sebagainya. Ketiga, keluarga harus menerima kehadiran waria sebagai bagian dari keluarga dan memahami bahwa orientasi seksual tidak bisa dipilih, ia adalah pemberian dari Tuhan. Karena orientasi seksual adalah pemberian (given), maka tugas manusia harus menerima pemberian itu sebagai suatu ketetapan Tuhan (takdir), tanpa harus menyingkirkan sanak keluarga yang dianggap "berbeda". Dari penerimaan keluarga itu, maka nanti akan menjadi pendorong dan menjadi magnet bagi teman sepermainan dan lingkungan hidup waria untuk menerima kehadirannya sebagai makhluk Tuhan yang terhormat dan bermartabat (alharakah al-insaniyah/human dignity) Keempat, pemerintah. Di sini pemerintah bertugas sebagai pelindung hukum atas warga masyarakat yang mengalami diskriminasi berlapis dari pelbagai multi dimensi. Untuk lebih jelasnya lihatlah tabel di bawah ini:

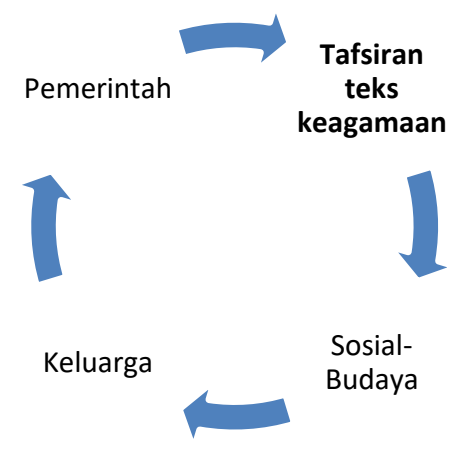

Tabel 02: Mata Rantai Kekerasan Waria

Peran serta antara pemerintah, masyarakat dan waria sendiri dilakukan sebenarnya untuk mengubah paradigma atau cara pandang masyarakat umum tentang sosok "waria", yang keberadaannya di muka bumi seolah-olah tidak ada, keberadaan waria tidak dihargai dalam kehidupan real masyarakat. Maka agar keberadaan waria itu dilihat dengan pemenuhan hak asasi, penghormatan sebagai manusia, dan perlakuan yang manusia, maka saatnya masyarakat Indonesia mengubah cara pandang tentang waria.

Perubahan cara pandang itu menjadi lebih sempurna manakala pemerintah mau untuk menghapus kekerasan terhadap waria yang tersirat dalam Perda No. 1 Tahun 2014 tentang Gelandangan dan Pengamen di Daerah Istimewa Yogyakarta manakala pemerintah berasaskan pada beberapa asas. ${ }^{22}$ Pertama, asas penghormatan hak asasi manusia. Tindakan kekerasan dalam bentuk apa pun dan kepada siapa pun merupakan bagian dari pelanggaran terhadap hak asasi manusia, karena setiap manusia dilahirkan dari pribadi yang merdeka dan melekat pada dirinya sebagai hak dasar yang tidak boleh dilanggar atau dirampas oleh orang lain. Kedua, asas keadilan dan kesetaraan gender. Tindakan kekerasan dalam konteks relasi personal lahir karena disebabkan oleh pola relasi kekuasaan yang timpang. Pola yang demikian ketika tersosialisasi dan terlembagakan maka pada gilirannya akan menciptakan

${ }^{22}$ Asas ini penulis sadur dari asas Undang-Undang RI Nomor 23 Tahun 2004 tentang KDRT. Penulis beranggapan bahwa asas yang disebutkan dalam UU KDRT hampir sama dengan asas keadilan untuk waria dalam hal substansi asas. Lihat Kementerian Pemberdayaan Perempuan RI, Undang-Undang RI No. 23 Tahun 2004 Tentang Penghapusan Kekerasan dalam Rumah Tangga. 
suatu sistem sosial yang tidak adil gender. Ketiga, asas non diskriminasi. Asas ini memberikan suatu jaminan bahwa dalam upaya penghapusan kekerasan terhadap waria tidak mendasarkan pada perlakuan yang diskriminatif baik karena perbedaan orientasi seksual, strata sosial, profesi, dan lain sebagainya. diharapkan dengan asas ini, semua warga negara di hadapan hukum adalah sama baik hak dan kewajibannya. Sehingga perlakuan yang diskriminatif pada seseorang adalah bagian dari pelanggaran hak asasi manusia.

\section{F. Penutup}

Waria sebagai anggota keluarga, sebagai anggota masyarakat, sebagai warga negara, sebagai makhluk Tuhan, sejatinya harus dipandang sebagaimana layaknya manusia dengan hak-hak yang melekat dalam dirinya. Perlu disadari di sini, bahwa tidak ada waria yang ingin terlahir sebagai waria yang terdiskriminasi dari keluarga, yang menggantungkan hidup dari mengamen dan penjaja seks dan termarginalkan dalam lingkup sosial industri. Waria tidak memiliki kuasa untuk memilih hidup sebagai waria dengan atribut persoalan hidup yang melekat dalam dirinya. Padahal dalam konteks relasi sosial, tidak semua waria cenderung meresahkan masyarakat, melakukan pembunuhan, korupsi yang merugikan negara, dan perbuatan kriminal lainnya. Sebagai makhluk Tuhan, waria tidak dapat menutup dirinya dari insting dan naluri ketuhanan. Oleh karenanya, sungguh ironi manakala ada orang lain atas nama "keamanan" sosial, norma sosial, nilai sosial, agama, dan lain sebagainya merebut hak orang lain untuk mengespresikan dirinya.

Sudah saatnya kita melihat waria dari sudut pandang waria, melihat waria dari kacamata waria, bukan dari sudut pandang dan kacamata kita sebagai manusia mayoritas dengan prestise sosial yang dimiliki. Terakhir, penulis kutip harapan dan mimpi pendiri Pondok Pesantren Waria Al-Fattah Yogyakarta, almarhum Ibu Mariyani, "Mimpi dan harapan transgender adalah dapat diterima di masyarakat, terutama dalam lapangan pekerjaan sehingga membuat perusahaan-perusahaan terbuka untuk menerima transgender sebagai bagian dari tenaga kerja. Kemudian, membuat kolega kerja untuk menghormati harkat transgender, agar dapat bekerja dan bebas dari diskriminasi maupun cemoohan". ${ }^{23}$

\section{DAFTAR PUSTAKA}

"Ironi Jogja: Ditetapkan Kriminal Hanya Karena Mereka Miskin, Sedangkan Pembangunan Industri Pariwisata dan Properti Begitu Dilayani”, edisi 9 Juni 2016, https://kaukusperdagepengdiy.wordpress.com

"Selama Persyaratan Lengkap, Pemkot Yogyakarta Akui Tak Bisa Menolak Pembangunan Hotel", edisi Selasa, 12 April 2016 dalam http://jogja.tribunnews.com

Abdulhadi, Rabab, "Sexualities and The Social Order in Arab and Muslim Communities", dalam Samar Habib, Islam and Homosexuality, Amerika Serikat: ABC-CLIO, 2010.

Atmojo, Kemala, Kami Bukan Laki-Laki, Jakarta: Grafitti Pers, 1987.

Danadjaja, James, "Homoseksual atau Heteroseksual” dalam Srintil: Menggugat Maskulinitas \& Feminitas, Jakarta: Kajian Perempuan Desantara, 2003.

Hak-Hak Seksual: Deklarasi IPPF, diterbitkan oleh International Planned Parenthood Federation London, 2008.

\footnotetext{
${ }^{23}$ Hartoyo dkk, Sesuai Kata Hati: Kisah Perjuangan 7 Waria, Jakarta: Rehal Pustaka, 2014, hlm. 111.
} 
Hartoyo dkk, Ekspresi untuk Identitas, Jakarta: Suara Kita, PKBI, dan Renebook, 2014.

Hartoyo dkk, Sesuai Kata Hati: Kisah Perjuangan 7 Waria, Jakarta: Rehal Pustaka, 2014.

Identitas Seksual dan HAM, http://aruspelangi.org, diakses pada 19/04/2015.

Kartono, Kartini, Psikologi Abnormal \& Abnormalitas Sexual, Bandung: Mandar Maju, 1989.

Kementerian Pemberdayaan Perempuan RI, Undang-Undang RI No. 23 Tahun 2004 Tentang Penghapusan Kekerasan dalam Rumah Tangga.

Mulia, Musdah, Mengupas Seksualitas: Mengerti Arti, Fungsi, dan Problematika Seksual Manusia Era Kita, Jakarta: Opus Press, 2015.

Oetomo, Dede, Memberi Suara Pada Yang Bisu, Yogyakarta: Pusaka Marwa, 2003.

Peraturan Daerah Daerah Istimewa Yogyakarta Tentang Gelandangan dan Pengemis nomor 1 tahun 2014 dalam www.dprd-diy.go.id

Press Release "Perda Gepeng Membunuh Kami", edisi 26 April 2016 https://kaukusperdagepengdiy.wordpress.com

Puspitosari, Hesti \& Sugeng Pujileksono, Waria \& Tekanan Sosial, Malang: UMM Press, 2005.

Ridwan, Kekerasan Berbasis Gender: Rekonstruksi Teologis, Yuridis, \& Sosiologis, Purwokerto: PSG STAIN, 2006.

Said, Tanti Noor, "Politik Gender \& Seksualitas: Transgender Indonesia dalam Konteks Masyarakat Indonesia dan Eropa Barat", dalam Jurnal Perempuan edisi 87 volume 20 no. 4 November 2015.

W. Lindsay Neustatter, "Aspek-Aspek Medis dalam Homoseksual”, dalam William A.R. Thomson (ed.), Sex dan Masalahnya, Yogyakarta: Yayasan Essentia Medica, 1987. 